Reprinted with permission from: Weed Technology. Oct/Dec 1991. 5:894-897.

Published and copyrighted by: Weed Science Society of America. http://www.wssa.net

\title{
Maximizing herbicide efficiency with mixtures and expert systems ${ }^{1}$
}

\author{
JENY M. GREEN
}

The author is Sr. Res. Biol., Agric. Prod. Dep., Stine-Haskell Res. Cent., E. I. du Pont de Nemours \& Co., Newark, DE 19714.

\begin{abstract}
:
A practical and objective system is needed to determine the lowest rates of the most efficacious herbicides to meet each producer's specific weed control problems. Determining which method of weed control to utilize is difficult today with increasing product choices, the growing use and complexity of herbicide mixtures, regulatory pressures to reduce rates, and the closer integration of weed control with other crop decisions. Expert computer systems could improve current practices and use herbicide mixtures as a tool to increase herbicide efficiency. Such systems would account for herbicide dose and mixture responses; select most economical herbicides; optimize adjuvants; recommend control at economic thresholds; and vary rates according to weed spectrum, density, and local environmental conditions. An example using chlorimuron and thifensulfuron illustrates how these systems could use quantitative dose response and mixture information.
\end{abstract}

\section{Nomenclature:}

Chlorimuron, 2-[[[[(4-chloro-6-meth-oxy-2-pyrimidinyl)amino $]$ carbonyl $]$ amino]sulfonyl] benzoic acid; thifensulfuron, 3-[[[[ (4-methoxy-6-methyl1,3,5-triazin-2yl) amino] carbonyl]-amino] sulfonyl]-2-thiophenecarboxylic acid.

\section{Additional index words:}

Herbicide interaction, dose response, LISA, environment, chlorimuron, thifensulfuron.

\footnotetext{
${ }^{1}$ Received for publication Dec. 21, 1990 and in revised form Oct. 15, 1991.
} 


\section{Introduction}

The use of herbicide mixtures is increasing and changing rapidly $(5,8,11)$. Herbicide use has evolved from high rates of single herbicides to low rates of three, four, and fiveway mixtures with one or two adjuvants that vary according to weed spectrum and environmental conditions $(11,14)$. More than 500 different mixtures are used in Europe each year (4). A person no longer can consider all mixture possibilities and complete the complex analyses needed to use herbicide mixtures efficiently $(3,4,9)$.

Increasing environmental and regulatory pressures encourage cultural practices that apply less herbicide and have resulted in several countries mandating herbicide reduction $(2,14)$ and similar proposals in the U.S. (17). Some experts already advocate herbicides by prescription only (19). In the future, producers will have to justify their herbicide applications.

The traditional practice of applying herbicides uniformly across fields and farms is obsolete (18). Variable-rate strategies save money, increase profits, reduce soil erosion, and improve groundwater quality. Unfortunately, these strategies require producers to take more time when they can least afford it.

Today, producers do not utilize quantitative information on herbicide dose response and interactions with other chemicals. Herbicide labels recommend few rate ranges and classify weeds only as controlled or suppressed. Consequently, herbicides often are applied at the same rates in mixtures as they are alone.

Determining which method of weed control to utilize is very difficult today with so many herbicide choices, the growing use and complexity of herbicide mixtures, regulatory pressures to reduce rates, and the closer integration of weed control with other crop decisions. Expert systems which are under development or already commercially available address many of these factors ${ }^{2,3}(2,15,16)$, but none effectively addresses mixtures.

This article suggests how these systems should use quantitative information on dose responses and interactions to reduce rates and still maintain performance.

\section{Mixture analysis}

The herbicide mixture model used the log-logit response equation for the dose response model (4)

$$
\mathrm{Y}=\log (\mathrm{y} /(100-\mathrm{y}))=\mathrm{a}_{1}+\mathrm{b}_{1} \log (\mathrm{x})
$$

where $\mathrm{Y}$ is the logit response, $\mathrm{y}$ is the $\%$ response, $\mathrm{x}$ is the herbicide rate, $\mathrm{a}_{1}$ is the intercept, and $b_{1}$ is the slope.

\footnotetext{
${ }^{2}$ Soybean Herbicide Selection Program, Arkansas Coop., Ext. Serv., P.O. Box 391, Little Rock, AR 72203, U.SA.

${ }^{3}$ Herb Software, P.O. Box 7620, Crop. Sci. Dep., N. C. State Univ., Raleigh, NC 27695, U.S.A.
} 
Mixture performance was protected from these response equations with the equivalents model (EQM) (12)

$$
\mathrm{Y}_{1+2}=\mathrm{p}\left(\mathrm{a}_{1}+\mathrm{b}_{1} \log \left(\mathrm{x}_{1}+\Theta \mathrm{x}_{1(2)}\right)\right)+\mathrm{q}\left(\mathrm{a}_{2}+\mathrm{b}_{2} \log \left(\mathrm{x}_{2}+\Theta \mathrm{x}_{2(1)}\right)\right)
$$

where $Y_{1+2}$ is the mixture response expressed as logit, $x_{1}$ and $x_{2}$ are the herbicide rates, $\mathrm{x}_{1(2)}$ and $\mathrm{x}_{2(1)}$ are the equivalent rates of each herbicide expressed as the other, and $\Theta$ quantifies additive action. A simpler model may be used when parallel response curves and additive action are assumed (12).

Biological data were obtained from 189 field tests by university researchers and DuPont development personnel from 1987 to 1990 using chlorimuron and thifensulfuron applied postemergence. Tests were performed in soybean growing areas throughout the United States. All treatments had two adjuvants, ammonium-based fertilizer and nonionic surfactant. Adjuvant types met product label requirements ${ }^{4}$ and increased performance $(9$, 10). Weed observations were made 15 to 30 days after treatment (DAT) ${ }^{5}$ and soybeans [Glycine $\max$ (L.) Meir.] were observed 7 to 21 DAT. No other selection criteria were used. Data were analyzed with the log-logit model, and rates were determined for $10 \%$ injury or $90 \%$ control with associated confidence interval.

\section{Examples}

\section{Single herbicides}

Table 1 compares the response of chlorimuron and thifensulfuron on several weeds and soybeans. Both herbicides controlled broadleaf weeds, but their spectrums differed significantly. Both, like other herbicides (7), controlled weeds below recommended rates. For example, $2 \mathrm{~g} \mathrm{ha}^{-1}$ thifensulfuron controlled redroot pigweed (Amaranthus retroflexus L. \# ${ }^{6}$ AMARE), but velvetleaf (Abutilon theophrasti Medicus. \# ABUTH) required the full recommended rate, $5 \mathrm{~g} \mathrm{ha}^{-1}$. Adjusting herbicide rates to weed spectrum is a well known method to reduce herbicide rates ${ }^{3,4}(6,14)$.

Thifensulfuron and chlorimuron performed differently on common lambsquarters (Chenopodium album L. \# CHEAL) and common cocklebur (Xanthium strumarium L. \# XANST) (Table 1). Thifensulfuron controlled common lambsquarters at $4 \mathrm{~g} \mathrm{ha}^{-1}$, but chlorimuron required more than $50 \mathrm{~g} \mathrm{ha}^{-1}$. In contrast, $6 \mathrm{~g} \mathrm{ha}^{-1}$ chlorimuron controlled common cocklebur versus $14 \mathrm{~g} \mathrm{ha}^{-1}$ thifensulfuron.

\footnotetext{
${ }^{4}$ Classic ${ }^{\circledR}$ and Pinnacle ${ }^{\circledR}$ Product Labels, E. I. du Pont de Nemours \& Co., Wilmington, DE 19898, U.S.A.

${ }^{5}$ Abbreviations: DAT, days after treatment.

${ }^{6}$ Letters following this \# symbol are a WSSA-approved computer code from Composite List of Weeds, Revised 1989. Available from WSSA, 309 W. Clark St., Champaign, IL 61820.
} 
In addition to weed control, soybean injury and rotational crop flexibility must be considered. Chlorimuron was less phytotoxic to soybeans, but has rotational crop restrictions under certain conditions. The thifensulfiron rate that controlled common cocklebur was greater than its $10 \%$ injury rate (Table 1 ). A mixture with chlorimuron would control common cocklebur but would increase the rotational crop restrictions in high $\mathrm{pH}$ soils or in soils previously treated with imazaquin $\{2$-[4,5-dihydro-4-methyl-4-(1-methylethyl)5oxo-1 $H$-imidazol-2-yl]-3-quinolinecarboxylic acid $\}$, imazethapyr $\{( \pm)$-2-[4,5-dihydro-4methyl-4-(1-methylethyl)-5-oxo-1H-imidazol-2-yl]-5-ethyl-3-pyridinecarboxylic acid\} or chlorimuron preemergence ${ }^{4}$. In contrast, thifensulfuron degrades very rapidly in soil and does not have rotational crop restrictions after 45 days ${ }^{4}$. Maximizing the efficiency of just two herbicides on four weeds is complex, even before mixtures are considered.

Table 1. Comparison of chlorimuron and thifensulfuron rates to control weeds $90 \%$ or injure soybeans $10 \%$ with surfactant and ammonium fertilizer adjuvants. Results are from 189 U.S. field tests. The associated $90 \%$ confidence intervals are in parentheses.

\begin{tabular}{lcc}
\hline & Chlorimuron & Thifensulfuron \\
\cline { 2 - 3 } Crop & $21(14-30)$ & $10 \%$ Injury rate $\left(\mathrm{g} \mathrm{ha}^{-1}\right)$ \\
Soybeans & \multicolumn{2}{c}{$90 \%$ Control rates $\left(\mathrm{g} \mathrm{ha}^{-1}\right)$} \\
\cline { 2 - 2 } Weeds & $6(3-10)$ & $14(9-23)$ \\
Common cocklebur & 50 & $4(2-7)$ \\
Common lambsquarters & $8(4-15)$ & $2(1-4)$ \\
Redroot pigweed & $12(6-22)$ & $5(3-8)$ \\
Velvetleaf &
\end{tabular}

\section{Mixtures}

Thifensulfuron at $4 \mathrm{~g} \mathrm{ha}^{-1}$ controlled common lambsquarters (Table 1). Chlorimuron was less than one-tenth as active as common lambsquarters, requiring more than $50 \mathrm{~g} \mathrm{ha}^{-1}$ (Table 1). Consequently, a mixture of chlorimuron with thifensulfuron would not significantly reduce the thifensulfuron needed to control common lambsquarters (Figure 1). 


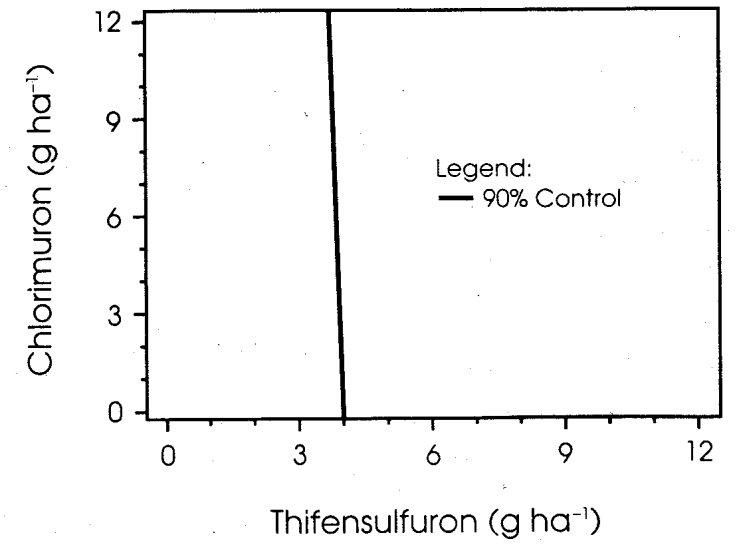

Figure 1. Chlorimuron and thifensulfuron Figure 2. Chlorimuron and thifensulfuron rates needed to control common lambs- rates needed to control common cocklebur quarters $90 \%$ (solid line).

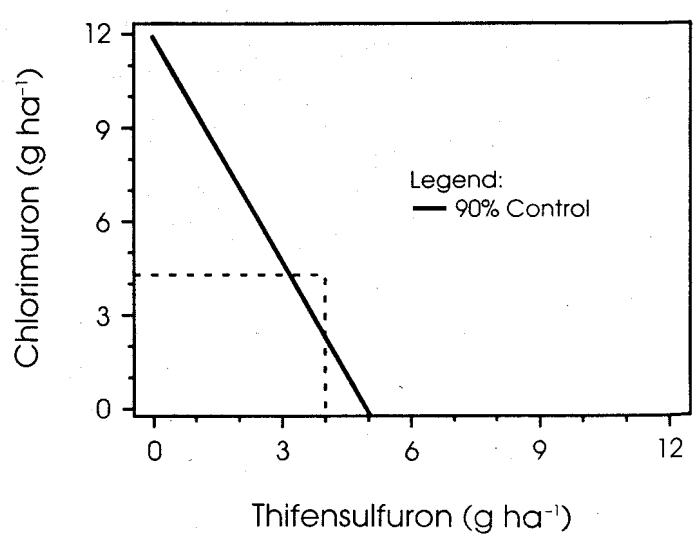

$\mathbf{9 0 \%}$ (solid line). Dash line is the minimum thifensulfuron rate that controls common lambsquarters.

Chlorimuron at $6 \mathrm{~g} \mathrm{ha}^{-1}$ controlled common cocklebur (Table 1). Thifensulfuron was less than half as active and required $14 \mathrm{~g} \mathrm{ha}^{-1}$, a rate that injured soybeans more than $10 \%$. However, if $4 \mathrm{~g} \mathrm{ha}^{-1}$ thifensulfuron was already present for common lambsquarters control, the chlorimuron rate could be reduced. With additive action, $4 \mathrm{~g} \mathrm{ha}^{-1}$ thifensulfuron provides $28 \%$ of the potency needed to control common cocklebur. Hence, $4 \mathrm{~g} \mathrm{ha}^{-1}$ thifensulfuron reduces the chlorimuron rate needed by $28 \%$ to $4.3 \mathrm{~g} \mathrm{ha}^{-1}$ (Figure 2). This mixture then would control both common lambsquarters and common cocklebur.

What if velvetleaf was also present? Used alone, thifensulfuron and chlorimuron could control velvetleaf, but velvetleaf needs more than the 4 or $4.3 \mathrm{~g} \mathrm{ha}^{-1}$ rates for common lambsquarters and common cocklebur control (Table 1). How much more herbicide is required? Although neither herbicide alone would control velvetleaf $90 \%$, their additive action would be more than enough. Thifensulfuron at $4 \mathrm{~g} \mathrm{ha}^{-1}$ has $80 \%$ of the potency needed, and $4.3 \mathrm{~g} \mathrm{ha}^{-1}$ chlorimuron has $36 \%$ (Figure 3 ).

Many other mixture examples illustrate reducing rates $(12,14)$. For example, metribuzin [4-amino-6-(1,1-dimethylethyl)-3-(methylthio)-1,2,4-triazin-5(4H)-one], a broadleaf herbicide that also suppresses grasses, and clomazone \{2-[(2chlorophenyl)methyl]4,4-dimethyl-3-isoxazolidinone], a grass herbicide that also controls velvetleaf, act synergistically and control most weeds at low rates (21). Adding a third herbicide like chlorimuron or imazaquin could reduce the total rate further, but dramatically increases the complexity of determining the best mixture. Using half-recommended rates is often effective (21), but weed scientists should determine mixture rates more precisely. 


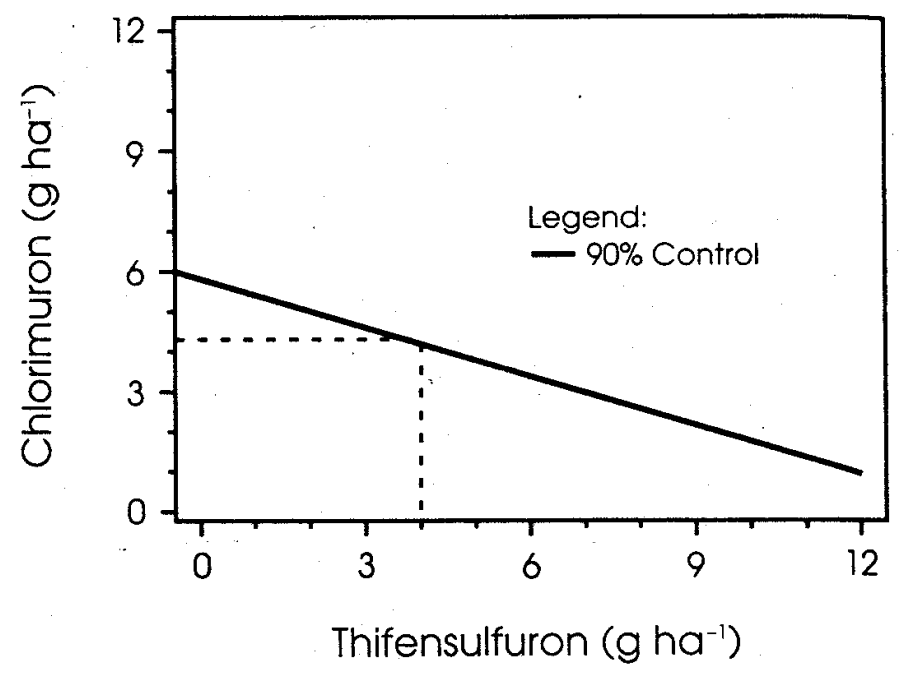

Figure 3. Chlorimuron and thifensulfuron rates needed to control velvetleaf $90 \%$ (solid line). Dash lines are the minimum rates that control common lambsquarters and common cocklebur.

\section{Discussion}

Today, with so many herbicide products available, dealers cannot adequately consider all possibilities for a producer. North Carolina dealers have access to more than 50 products for soybeans alone (1). Many dealers offer fewer products so they can develop expertise on their products and reduce inventory costs (1).

The need for expert systems increases as mixtures become more complex and weed control decisions are integrated more closely with other cropping decisions (13). Public pressures will continue to call for reduced herbicide rates. Producers who uniformly apply herbicides across their farms will soon have to customize according to weed spectrum and density in each section of their fields (18).

Herbicide mixtures often will be the best method to improve control and reduce herbicide rates. Weed scientists face the paradox that as knowledge and weed control options increase, decisions become more complex. At one time, the basic challenge was to determine the most economical combination of herbicides and cultural practices for each weed in each crop (20). However, today the challenge is more complex, and many other issues such as net profit, long-term sustainability, and the environment must be considered.

Expert systems are needed for herbicide mixtures because most crops have too many practical possibilities to consider and the calculations needed are complex. Expert systems are ideally suited to evaluate these complex problems and objectively recommend the most effective, economical, and environmentally compatible control method for each weed control situation. 


\section{Literature cited}

1. Anonymous. 1989. An argument for being choosy. Agrichemical Age. 33(8):14-15.

2. Baandrup, M., and T. Ballegaard. 1989. Three years of field experience with an advisory computer system applying factor-adjusted doses. Proc. Brighton Crop. Prot. Conf. Weeds 4:555-563.

3. Barrett, M., and W. W. Witt, 1987. Maximizing pesticide use efficiency. p. 235-255 in Z. Helsel, ed. Energy in World Agriculture Handbook. Elsevier Science Publishers, Amsterdam, Netherlands.

4. Berkson, J. 1944. Application of the logistic function to bioassay. J. Am. Stat. Assoc. 39:357-365.

5. Boedeker, W. R., Altenburger, M. Faust and L. H. Grimme. 1990. Methods for the assessment of mixtures of plant protection substances (pesticides): Mathematical analysis of combination effects in phytopharmacology and ecotoxicology. Nachrichtenbl. Deut. Pflanzenschutzd. (Braunschweig) 42:70-78.

6. Combellack, J. H. 1990. Efficient utilization of herbicides. Proc. Australian Weeds Conf. 9:1-7.

7. DeFelice, M. S., W. B. Brown, R. J. Aldrich, B. D. Sims, D. T. Judy, and D. R. Guethle. 1989. Weed control in soybeans (Glycine max) with reduced rates of postemergence herbicides. Weed Sci. 37:365374.

8. Delvo, H. W. 1987. Herbicide use in wheat and soybean production. Proc. North Cent. Weed Control Conf. 42:28-29.

9. Fielding, R. J., and E. W. Stoller. 1989. Effects of additives on efficacy, uptake, and translocation of chlorimuron ethyl ester. Weed Technol. 4:254-271.

10. Green, J. M. 1988. Effect of inorganic salts on the efficacy of chlorimuron and DPX-M6316 on soybeans. Abstr. Weed Sci. Soc. Am. 28:16.

11. Green, J. M. 1989. Herbicide antagonism at the whole plant level. Weed Technol. 3:217-226.

12. Green, J. M., and S. P. Bailey. 1988. Herbicide interactions with herbicides and other agricultural chemicals. p. 37-61 in C. G. McWhorter and M. R. Gebhardt, eds. Methods of Applying Herbicides. Weed Sci. Soc., Am., Champaign, IL.

13. Jones, J. W., P. Jones, and P. A. Everett. 1987. Combining expert systems and agricultural models: A case study. Transactions of the ASAE 30(5):1308-1314.

14. Kudsk, P. 1989. Experiences with reduced herbicide doses in Denmark and the development of the concept of factor-adjusted doses. Proc. Brighton Crop Prot. Conf. Weeds 4:545-554.

15. Linker, H. M., A. C. York, and D. R. Wilhite, Jr. 1990. WEEDS - A system for developing a computerbased herbicide recommendation program. Weed Technol. 4:380-385.

16. Martin, A. R. 1984. A computer program for herbicide selection. Abstr. Weed Sci. Soc. Am. 25:51.

17. Mueller, W. 1990. The congressional deluge: Part 2. Agrichemical Age. 34(2):12-28.

18. Reichenberger, L., and J. Russnogle. 1989. Farm by the foot. Farm J. 113(6):11-15.

19. Richardson, L. 1990. Back talk: Bucharest. Agrichemical Age. 34(2):30.

20. Willard, C. J. 1951. Where do we go from here? Weed 1:9-12.

21. Westberg, D. B., L. R. Oliver, and R. E. Frans. 1989. Weed control with clomazone alone and with other herbicides. Weed Technol. 3: 678-685. 